\title{
Alpha-tubulin promoter from Chlorella vulgaris allows genetic transformation of green coccoid microalga
}

\section{El promotor de la alfa-tubulina de Chlorella vulgaris permite la transformación genética de la microalga verde tipo cocoide}

Raquel Fernández-Rodríguez ${ }^{1}$, Giovanni Garro-Monge², Maritza Guerrero-Barrantes ${ }^{3}$, Olman Gómez-Espinoza ${ }^{4}$

Fernández-Rodríguez, R; Garro-Monge, G; Guerrero-Barrantes, M; Gómez-Espinoza, O. Alpha-tubulin promoter from Chlorella vulgaris allows genetic transformation of green coccoid microalga. Tecnología en Marcha. Vol. 33-2. Abril-Junio 2020. Pág 27-36.

doi) https://doi.org/10.18845/tm.v33i2.4155

1 Ingeniera en Biotecnología. Centro de Investigación en Biotecnología, Escuela de Biología, Instituto Tecnológico de Costa Rica. Costa Rica. Correo electrónico: raquel_fernandezr@hotmail.com.

2 Biólogo. Máster en Genética. Centro de Investigación en Biotecnología, Escuela de Biología, Instituto Tecnológico de Costa Rica. Costa Rica. Correo electrónico: ggarro@tec.ac.cr.

(iD https://orcid.org/0000-0001-7578-1938

3 Bióloga. Máster en Ecología. Centro de Investigación en Biotecnología, Escuela de Biología, Instituto Tecnológico de Costa Rica. Costa Rica. Correo electrónico: mguerrero@tec.ac.cr

4 Ingeniero en Biotecnología. Máster en Biología Celular y Molecular Aplicada. Centro de Investigación en Biotecnología, Escuela de Biología, Instituto Tecnológico de Costa Rica. Costa Rica. Correo electrónico: oespinoza@tec.ac.cr. 


\title{
Palabras clave
}

Electroporación; kazusa; estreptomicina; transgénico; Caja TATA.

\section{Resumen}

Las microalgas se han convertido en una plataforma viable para la producción de proteínas recombinantes de alto valor. Aunque se han desarrollado diversos conjuntos de herramientas genéticas para la transformación de microalgas, algunos elementos críticos, como los promotores endógenos, deben mejorarse para aumentar los niveles de expresión génica posterior al proceso de transformación. Para contribuir a ello, el presente estudio tuvo como objetivo evaluar una secuencia de la región 5' del gen alfa-tubulina de Chlorella vulgaris, como promotor para la expresión de un gen resistencia a antibiótico en Chlorella sorokiniana. Mediante análisis in silico se logró identificar un promotor proximal correspondiente a 281 nucleótidos corriente arriba del codón de inicio ATG, el cual poseía 9 potenciales elementos reguladores en cis, incluyendo Caja TATA y Caja CAAT. La secuencia promotora proximal se usó para dirigir la expresión de un gen de resistencia a la estreptomicina (aada), previa optimización de su uso de codones. La optimización de codones de la secuencia aada permitió obtener un contenido de GC del 69,8\% (en comparación con el 53\% del gen original), lo que aumenta su similitud con los genomas de Chlorella sp. (67,2\%). Ambos elementos genéticos se clonaron en el vector pUC57-Kan y se transformaron en células de C. sorokiniana mediante electroporación. Las colonias de microalgas transgénicas fueron identificadas a través de cultivo en medio selectivo y PCR. Nuestros resultados demostraron la capacidad del promotor alfa-tubulina de Chlorella vulgaris para expresar un gen heterólogo de resistencia a antibiótico en células de C. sorokiniana. La investigación de secuencias promotoras endógenas es esencial para lograr una expresión génica heteróloga eficiente, especialmente en microalgas utilizadas para la producción industrial como las del género Chlorella.

\section{Keywords}

Electroporation; kazusa; streptomycin; transgenic; TATA-box.

\begin{abstract}
Microalgae have become a feasible platform for high-value recombinant protein production. Although diverse sets of genetic tools for microalgae transformation have been developed, some critical elements, such as endogenous promoters, need to be improved for increasing transgenic expression levels after genetic transformation. This work aimed to evaluate a sequence from the $5^{\prime}$ upstream region of the alpha-tubulin gene from Chlorella vulgaris as a promoter for the expression of an antibiotic resistant gene in Chlorella sorokiniana. Using in silico analysis it was possible to identify a proximal promoter corresponding to 281 nucleotides upstream of the ATG start codon, which possessed 9 potential cis-regulatory elements, including TATA Box and CAAT Box. The proximal promoter sequence was used to drive the expression of a streptomycinresistance gene (aada), previous optimization of its codon usage. The codon optimization of the aada sequence allowed investigators to obtain a GC content of 69,8\% (compared to 53\% of the original sequence), which increases its similarity with Chlorella sp. genomes (67,2\%). Both genetic elements were cloned into the pUC57-Kan vector and transformed into $C$. sorokiniana cells by electroporation. The microalgae transgenic colonies were identified through culture in selective medium and PCR. Our results proved the capacity of the Chlorella vulgaris alpha-tubulin promoter to express a foreign antibiotic-resistance gene in $C$. sorokiniana cells. Research of endogenous promoting sequences is essential in order to accomplish an efficient heterologous gene expression, especially in microalgae used for industrial production like those from Chlorella genus.
\end{abstract}




\section{Introduction}

Microalgae are a diverse and polyphyletic group of single-cell photosynthetic organisms, both eukaryotes and prokaryotes, which can easily grow in a wide range of habitats under photoautotrophic conditions [1]. To date, microalgae have gained considerable attention as a low cost model for the production of a wide range of commercial goods, such as food and animal feed additives, ingredients in cosmetics, or as value-added compounds (pigments, therapeutic proteins, fatty acids) [2]. More recently, microalgae have been also the object of an increasing interest as alternative host for recombinant protein production because of their economic benefits and ecofriendly characteristics [3], [4].

Despite their inherent advantages as biological factories for the large-scale production of recombinant molecules [5], [6]; the number of microalgae species that have been genetically modified has increased slowly and it is still scarce [7]. One of the main obstacles which limits the development of microalgae genetic engineering is the lack of plasmid vectors with all the essential elements for their transformation [8]. Among the critical elements for an efficient expression of the biomolecules, the use of specific promoters for microalgae stands out; however, the lack of endogenous promoters is one of the main drawbacks to achieving an efficient transformation [9], [10].

The promoters are cis-acting regulatory regions that direct the transcription of a gene. Functionally, a promoter is a DNA sequence located upstream (towards the 5' end of the coding region of a gene) that includes the binding regions for transcription factors [11]. In microalgae, some heterologous promoters, including the cauliflower mosaic virus (CaMV35S), ubiquitin promoter, and NOS, have been used for the expression of reporter genes [12]. Nevertheless, due to the unique nuclear characteristics of the microalgae, the gene expression under heterologous promoter control has been inefficient, exhibiting relatively low and fluctuating levels [13].

In contrast, the most effective promoters have derived from highly expressed microalgae genes; for instance, in the transformation of Chlamydomonas reinhardtii, the non-coding 5' region of the small RuBisCO (RBCS2) subunit gene and the heat shock protein 70A (HSP70A) have been widely used [8], [14]. While the use of endogenous promoters is almost optimized in model algal strains, only heterologous promoters from plant systems have been used in industrial microalgae strains like Chlorella sp. [2].

For species of the Chlorella genus, which represent a specialized group of green microalgae that can produce high protein levels, genetic transformation development has been slow and research on promoters derived from Chlorella is still in its early stage [15]. Therefore, the identification and isolation of new and effective endogenous promoters is highly required to achieve an efficient expression of foreign genes in Chlorella sp. [16]. In this study, we predicted an endogenous Chlorella promoter sequence in the $5^{\prime}$ upstream region of the alpha-tubulin gene from Chlorella vulgaris. The function of this promoter was confirmed through the expression of an antibiotic resistant gene in Chlorella sorokiniana.

\section{Materials and methods}

\section{Chlorella strain and culture conditions}

Chlorella sorokiniana used in this study came from the microalgae culture collection of the Costa Rican Institute of Technology Biotechnology Research Center. Cells were routinely grown and maintained at $25^{\circ} \mathrm{C}$ in BG-11 medium [17] under 12/12 h light and dark cycle and $200 \mu^{-10 l} \mathrm{~m}^{-2}$ $\mathrm{s}^{-1}$ light intensity. 
Antibiotic sensitivity test

The tolerance of $C$. sorokiniana to streptomycin and spectinomycin antibiotics was evaluated through a sensitivity assay, streaking the plate with $50 \mu \mathrm{L}$ of the microalgae culture $\left(10^{6} \mathrm{cells} \mathrm{mL}^{-1}\right)$ in BG-11 agar supplemented with different concentrations of streptomycin and spectinomycin $\left(0,25,50,75,100,125\right.$, and $\left.150 \mathrm{mg} \mathrm{L}^{-1}\right)$. The plates were incubated inverted in darkness for two days, at room temperature, before being exposed to light conditions $\left(200 \mu \mathrm{mol} \mathrm{m} \mathrm{m}^{-2} \mathrm{~s}^{-1}\right)$, and the microalgae growth was determined 8 days later.

\section{Vector design and codon optimization}

The alpha-tubulin gene (tua1) of Chlorella vulgaris microalgae (GenBank accession: D16504.1) was identified through a BLAST search [18]. Using the information provided in the 5' non-coding region, exons, and introns of the DNA sequence [19], a minimal promoter region (proximal promoter) was identified; this sequence was named " $\alpha-1$ tubulin promoter". The location and distribution of putative cis-acting elements in $\alpha-1$ tubulin promoter was analyzed using PlantCARE [20].

The $\alpha-1$ tubulin promoter was used to drive the expression of the aadA gene, which codifies the streptomycin-3"-adenylyltransferase enzyme and provides resistance to the streptomycin antibiotic. The nucleotide sequence of the aadA gene was obtained from the pAPR52 plastid transformation vector (GenBank accession: EU497669.1). To achieve an efficient translation of the enzyme, an optimization in the use of the codons was performed, in order to adapt the sequence of the aad $A$ gene to the $C$. sorokiniana genome following the codon table for $C$. sorokiniana microalgae, obtained from Kazuza database [21].

Afterwards, the sequence optimization was performed using Optimizer [22]. The promoter sequence and the streptomycin resistance gene were synthesized along with the rep (pMB) and $n t p / l\left(\mathrm{Kn}^{\mathrm{R}}\right)$ gene sequences (resistance to the kanamycin antibiotic) of the pUC57-Kan vector for their replication in E. coli, through General Biosystems Inc.. The new vector was identified as pChlorella_1.

\section{Electrotransformation}

C. sorokiniana was transformed with pChlorella_1 vector through electroporation. Briefly, 30 $\mathrm{mL}$ of the $C$. sorokiniana culture $\left(\mathrm{OD}_{750}=0,3-0,5\right)$ were centrifuged at $4000 \mathrm{rpm}$ for $15 \mathrm{~min}$ and the supernatant was discarded. Then, the pellet was resuspended in $5 \mathrm{~mL}$ of GeneArt ${ }^{\circledR}$ MAX Efficiency Transformation Reagent (Thermo Fisher Scientific Inc., USA), and after its incubation for 30 min at room temperature, it was centrifuged once again and the supernatant discarded.

The cells were resuspended in $1250 \mu \mathrm{L}$ of the same reagent, and $4 \mu \mathrm{g}$ of previously $\mathrm{Xbal}$ linearized pChlorella_ 1 plasmid were added and incubated at $4{ }^{\circ} \mathrm{C}$ for $5 \mathrm{~min}$. A volume of 250 $\mu \mathrm{L}$ of the cell-DNA mix was transferred to a cold electroporation bucket (in an ice bath) and the electroporation was performed using an Eppendorf Eporator $\AA$ (Eppendorf AG, Germany), with 1 pulse at $1000 \mathrm{~V}(\sim 30 \mathrm{~ms})$.

After the electroporation process, the cells were transferred to a well plate with $5 \mathrm{~mL}$ of BG-11 medium with $40 \mathrm{mM}$ sucrose and they were incubated for 2 days at $120 \mathrm{rpm}$ and light conditions $\left(200 \mu \mathrm{mol} \mathrm{m} \mathrm{m}^{-2} \mathrm{~s}^{-1}\right)$. After the incubation period, the cells were harvested through a centrifugation at $2500 \mathrm{rpm}$ for $5 \mathrm{~min}$, resuspended in $100 \mu \mathrm{L}$ of BG-11 medium and streaked in Petri dishes with BG-11-agar supplemented with $125 \mathrm{mg} \mathrm{L}^{-1}$ of streptomycin (selective medium). The Petri dishes were incubated for 2 days at room temperature in the dark, and then they were exposed to continuous light conditions. 


\section{PCR analysis of transformants}

To confirm that $C$. sorokiniana was transformed, a "colony-PCR" of resistant colonies was performed, using specific primers for the streptomycin resistance gene: pchlorella_1_Forward 5'-TGTCTCTGGTTTGGTGGTCA-3' and pchlorella_1_Reverse 5'-CAGCAGGTCGTTGATCAGG-3'. The amplified product was expected to be of $385 \mathrm{pb}$. The PCR reaction was carried in a total volume of $25 \mu \mathrm{L}$, containing 2,5 $\mu \mathrm{L}$ of Dream Taq 10X Buffer, $1 \mu \mathrm{L}$ dNTPs (2 mM), $1 \mu \mathrm{L}$ of each primer $(10 \mu \mathrm{M}), 0,25 \mu \mathrm{L}$ of DreamTaq DNA Polymerase $\left(5 \mathrm{U} \mathrm{mL}^{-1}\right), 14,25 \mu \mathrm{L}$ of nuclease-free water and $5 \mu \mathrm{L}$ of colony lysate.

A thermal cycler (Applied Biosystems Veriti ${ }^{\circledR}$ ) was used for all reactions and the following thermal profile was applied: 30 cycles of denaturation at $94^{\circ} \mathrm{C}$ for $30 \mathrm{sec}$, alignment at $55^{\circ} \mathrm{C}$ for $30 \mathrm{sec}$, and extension at $72{ }^{\circ} \mathrm{C}$ for $1 \mathrm{~min}$, with a final extension for $10 \mathrm{~min}$ at $72{ }^{\circ} \mathrm{C}$. The PCR products were analyzed through a 1,5\% agarose gel electrophoresis.

\section{Results and discussion}

Antibiotic sensitivity test

The growth of $C$. sorokiniana was complete inhibited at a $125 \mathrm{mg} \mathrm{L}^{-1}$ streptomycin concentration, while the minimum spectinomycin concentration that allowed the complete inhibition of the microalgae growth was $150 \mathrm{mg} \mathrm{L}^{-1}$ (table 1). Therefore, $125 \mathrm{mg} \mathrm{L}^{-1}$ of streptomycin was the concentration chosen for the posterior selection of the transformed colonies. It is known that streptomycin affects the growth and the photosynthetic activity of $C$. vulgaris through the inhibition of the synthesis of chloroplast proteins [23] and that a $40 \mathrm{mg} \mathrm{L}^{-1}$ concentration is enough to completely inhibit its growth [24]. However, C. sorokiniana presents a certain level of tolerance to aminoglycoside antibiotics [25], which relates to the high antibiotic concentration that was required to suppress the algae culture, when compared to reports from other species.

Table 1. Sensitivity of C. sorokiniana to different concentrations of streptomycin and spectinomycin

\begin{tabular}{|c|c|c|}
\hline $\mathrm{mg} / \mathrm{L}$ & Streptomycin & - \\
\hline 0 & - & - \\
\hline 25 & - & - \\
\hline 50 & - & - \\
\hline 75 & - & - \\
\hline 100 & ++ & + \\
\hline 125 & +++ & +++ \\
\hline
\end{tabular}

No inhibition ("-"), Inhibition ("+"), Strong inhibition ("++"), Complete inhibition ("+++")

\section{Vector design and codon optimization}

The identified proximal promoter sequence corresponded to 281 nucleotides upstream of the ATG start codon (figure 1). In silico analyses revealed the presence of 9 potential cis-acting elements including 1 TATA- and 2 CAAT-boxes (table 2). The eukaryotic consensus TATA-box is considered an essential element in determining the transcription start site (TSS) and also serves as binding site for the components of the basal transcription machinery; it is typically located at the -30 or -31 position, relative to the TSS in metazoans [26]. However, the identified TATA-box was located at -82 nucleotides upstream of the ATG start codon; this kind of motif localization is common in yeasts, where the TATA-box is usually located at the -200 to -50 relative to ATG [26]. 
1 tgatgCAAACAATTCTATTGATCATGCTGCATACTTCAATGCCTTGATGC

51 ACAAGGTCTCACAACAAGCATGTCCTCCCGCATGCACATCGTTTCCCCCT 101

102 CACAAAATCTGTCTCTGGTTTGGTGGTCAGCTGGCGTGTTTTGCGGGCGT 152

153 TCCCTCTTTCAGACACCACACCAGAGCGTCGCGCGCAAAACTTACAAAAT 203

204 TGGAAGACGCGTCCTCGTTCGCCGTCTGCTCCTCTTTCTTAAAGCCTCCA 254

\section{AGCCACCCAGCTTCTTTCTAAATCTGCAACC ATG 284}

CAAT-box $\square$ TATA-box $\square$ Box $S \quad$ Start codon (ATG)

Figure 1. Nucleotide sequence of the Chlorella vulgaris $\alpha-1$ tubulin promoter and its more relevant predicted motifs.

The TATA-box sequence found in Chlorella vulgaris $\alpha$-1 tubulin promoter (TACAAAA) has minor deviations in relation to the consensus TATA box DNA sequence. This type of variation, called weak TATA box, has been reported in different eukaryotic cells and also facilitates the interaction with the TATA-binding protein [27], [28]. The CAAT box, also found in the promoter, is known for its capability to regulate the transcription frequency [29].

Other studies reference the use of tubulin promoters for microalgae transformation; for instance, Davies et al. [30] fused the promoter region of the $\beta 2$-tubulin gene to the coding region of a genomic clone of arylsulfatase (ars), to form a chimeric tubB2/ars sequence, leading to an efficient microalgae transformation. Also, Hallmann and Sumper [31] achieved the functional expression of the Chlorella sp. HUP1 gene in Volvox carteri under the control of the constitutive promoter Volvox $\beta$-tubulin. Considering these previous examples, $\alpha-1$ tubulin promoter from Chlorella vulgaris is proposed as an effective promoter for the transformation of Chlorella sorokiniana.

Table 2. List of putative cis-acting elements in the $\alpha-1$ tubulin promoter in Chlorella vulgaris

\begin{tabular}{|c|c|c|}
\hline Name & Sequence & Function \\
\hline AAGAA-motif & GAAAGAA & Related with the stability of poly(A) sites \\
\hline ARE & AAACCA & $\begin{array}{c}\text { Cis-acting regulatory element essential for the } \\
\text { anaerobic induction }\end{array}$ \\
\hline CAAT-box & CAAT, CCAAT & $\begin{array}{c}\text { Common cis-acting element in promoter and } \\
\text { enhancer regions }\end{array}$ \\
\hline STRE & AGGGG & $\begin{array}{c}\text { Stress-responsive element } \\
\text { TATA-box }\end{array}$ \\
\hline Box S & TACAAAA & Core promonscription start \\
\hline RAV1A & AGCCACC & Pathogen-induced element \\
\hline ARFAT & CAACA & RAV1 recognition element \\
\hline SORLIP1 & TGTCTC & Auxin-responsive element \\
\hline
\end{tabular}


The aadA codon optimized sequence obtained a 69,8 \% GC content (compared with a $53 \%$ content of the original gene), which increases its likelihood to Chlorella sp.'s genome $(67,2 \%)$ [32] and its possibility to be translated efficiently. The designed vector (including the promoter and the aadA sequences) consisted of $3797 \mathrm{bp}$ and included the sequences necessary for its replication in E. coli (figure 2).

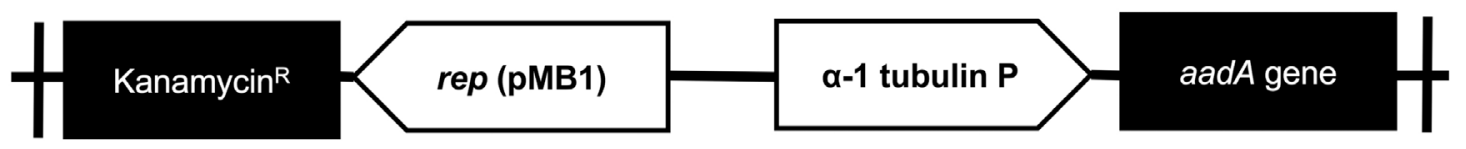

Figure 2. Map of the designed pChlorella_ 1 vector. $\alpha-1$ tubulin P: strong promoter, native from Chlorella vulgaris, which drives the expression of the aadA; addA gene: gene that codes for streptomycin-3 "-adenyltransferase and confers resistance to streptomycin; rep (pMB1): allows a high copy number replication and growth in E. coli; $\mathrm{Kn}^{\mathrm{R}}$ : kanamycin resistance gene, it allows the selection of the plasmid in E. coli.

\section{Electrotransformation and PCR analysis}

The transformation of C. sorokiniana with pChlorella_1 plasmid was induced through electroporation. For a higher transformation efficiency, the plasmid was linearized using Xbal restriction enzyme [33]. The GeneArt $囚$ MAX Efficiency Transformation Reagent was used, which is a commercial reagent for the transformation of Chlamydomonas reinhardtii that increases the permeability of the membrane. However, other authors have treated Chlorella sp. through osmosis with sorbitol, mannitol, $\mathrm{KCl}, \mathrm{CaCl}_{2}$ and HEPES, obtaining a similar effect [34]. After the electroporation process, microalgae growth was observed in the streptomycin selective medium, evidencing the positive result of the transformation. The negative control (electropored microalgae without the plasmid) was not able to survive in the medium with antibiotic (figure 3-a). The transformed microalgae were subjected to a direct PCR of random colonies to identify the aadA gene present in pChlorella_1. The PCR products showed positive results, achieving the expected size of approximately $400 \mathrm{pb}$. Therefore, it was possible to confirm the integration of the promoter sequence and the resistance gene in the nuclear DNA of the microalgae (figure 3-b). The results demonstrated that the modified permeabilization membrane protocol, as well as the voltage used are adequate for the transformation of $C$. sorokiniana. 
a.

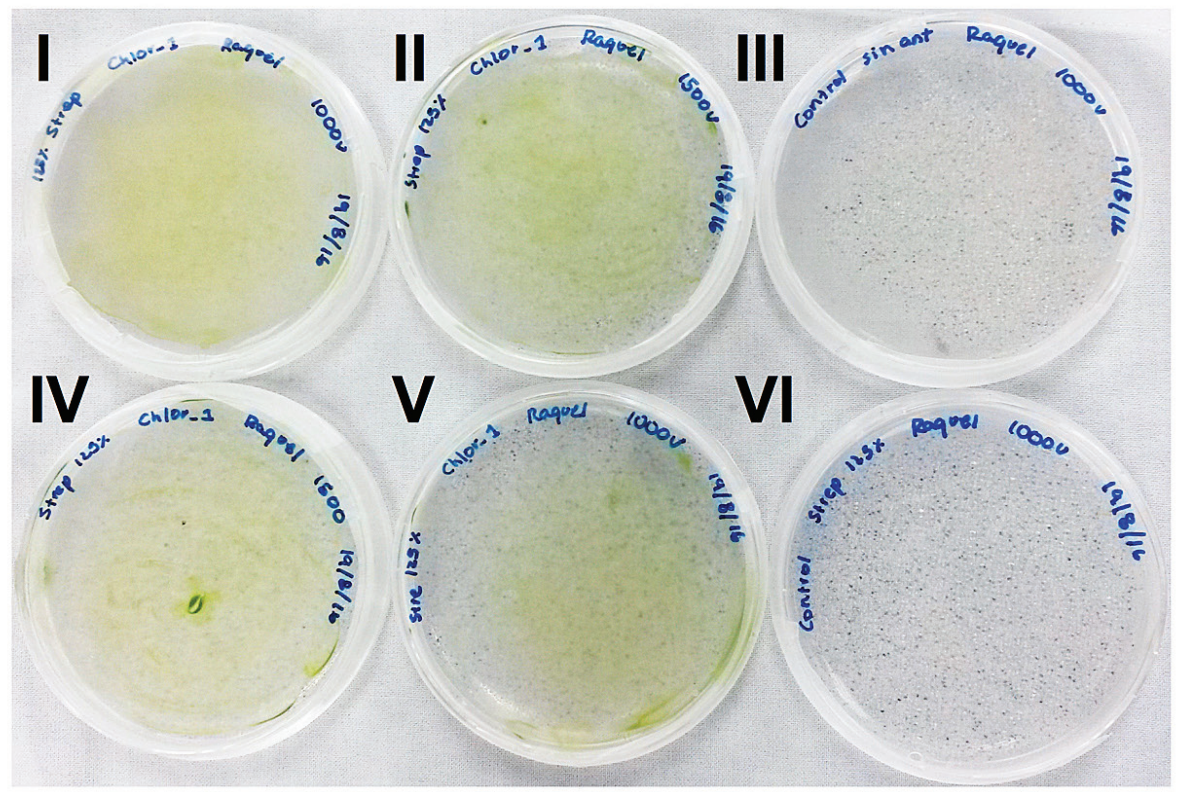

b.
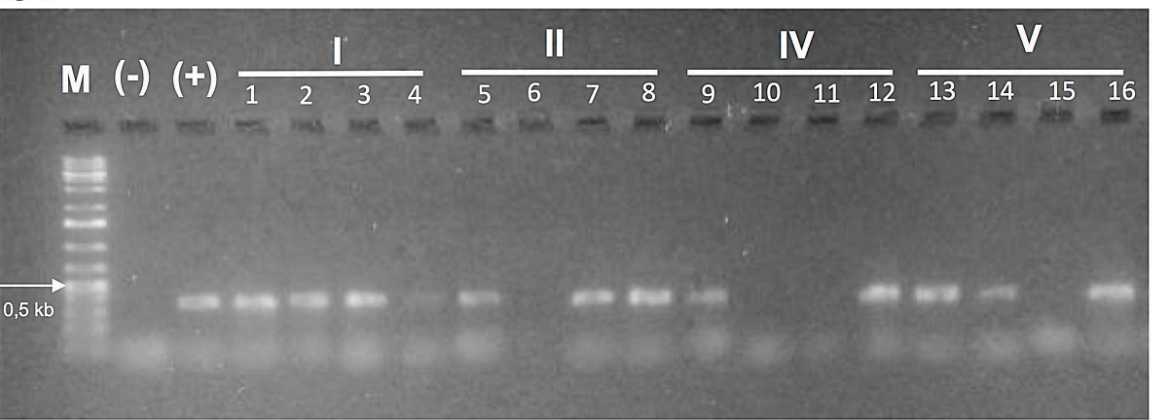

Figure 3. Transformation of $C$. sorokiniana with pChlorella_1 vector. a. Growth, in a selective medium, of $C$. sorokiniana transformed with pChlorella_1 (III and VI negative controls). b. Proof of the presence of the aadA gene in C. sorokiniana by colony polymerase chain reaction. The aadA gene was confirmed in all selected colonies except 6, 10, 11 and 15. M, 1-kb DNA ladder; (+) positive control, pChlorella_1 plasmid; (-) negative control; lanes 1-16, randomly selected colonies.

\section{Conclusion}

In this research, it was possible to achieve an efficient transformation through the electroporation of Chlorella sorokiniana with the pChlorella_1 vector. Our results proved the capacity of the Chlorella- $\alpha$-tubulin promoter to express a foreign antibiotic-resistance gene in $C$. sorokiniana cells. Further research is required to determine the stability and strength of this new promoter, as well as the addition of new genetic elements, including the multiple cloning site, intron, UTR. The stable transformation of the microalgae has been a slow process due to the reduced heterologous gene expression; hence, research of endogenous promoter sequences is essential in order to accomplish an efficient heterologous gene expression, especially in microalgae used for industrial production like those from Chlorella genus. 


\section{Acknowledgments}

This study was financed by Vicerrectoría de Investigación y Extensión del Instituto Tecnológico de Costa Rica. The authors thank Maria Valerio for the final English language revision service.

\section{References}

[1] L. Barsanti and P. Gualtieri, "Is exploitation of microalgae economically and energetically sustainable?," Algal Res., vol. 31, pp. 107-115, 2018.

[2] J. Kim, L. Liu, Z. Hu, and E. Jin, "Identification and functional analysis of the psaD promoter of Chlorella vulgaris using heterologous model strains," Int. J. Mol. Sci., vol. 19, pp. 1-14, 2018.

[3] B. A. Rasala, S. S. Chao, M. Pier, D. J. Barrera, and S. P. Mayfield, "Enhanced genetic tools for engineering multigene traits into green algae," PLoS One, vol. 9, no. 4, 2014.

[4] S. Lee et al., "Development of an alcohol-inducible gene expression system for recombinant protein expression in Chlamydomonas reinhardtii," J. Appl. Phycol., vol. 30, pp. 2297-2304, 2018.

[5] T. Thanh, V. T. Q. Chi, H. Omar, M. P. Abdullah, and S. Napis, "Sequence analysis and potentials of the native RbcS promoter in the development of an alternative eukaryotic expression system, using green microalga Ankistrodesmus convolutus," Int. J. Mol. Sci., vol. 13, no. 3, pp. 2676-2691, 2012.

[6] S. Jagadevan et al., "Recent developments in synthetic biology and metabolic engineering in microalgae towards biofuel production," Biotechnol. Biofuels, vol. 11, no. 1, pp. 1-22, 2018.

[7] P. Úbeda-Mínguez, T. Chileh, Y. Dautor, F. García-Maroto, and D. L. Alonso, "Tools for microalgal biotechnology: Development of an optimized transformation method for an industrially promising microalga-Tetraselmis chuii," J. Appl. Phycol., vol. 27, no. 1, pp. 223-232, Feb. 2015.

[8] Y. F. Niu et al., "A new inducible expression system in a transformed green alga, Chlorella vulgaris," Res. Genet. Mol. Res, vol. 10, no. 104, pp. 3427-3434, 2011.

[9] M. Vila, E. Díaz-Santos, M. De La Vega, H. Rodriǵuez, Á. Vargas, and R. León, "Promoter trapping in microalgae using the antibiotic paromomycin as selective agent," Mar. Drugs, vol. 10, no. 12, pp. 2749-2765, 2012.

[10] N. Yan, C. Fan, Y. Chen, and Z. Hu, "The potential for microalgae as bioreactors to produce pharmaceuticals," Int. J. Mol. Sci., vol. 17, no. 6, pp. 1-24, 2016.

[11] Z. M. De Guglielmo y R. Fernandez, "Principales promotores utilizados en la transformación genética de plantas," Rev. Colomb. Biotecnol., vol. 18, no. 2, p. 119, 2016.

[12] L. Doron, N. Segal, and M. Shapira, "Transgene expression in microalgae: From tools to applications," Front. Plant Sci., vol. 7, p. 505, 2016.

[13] B. Wang, J. Wang, and D. R. Meldrum, "Application of synthetic biology in cyanobacteria and algae," Front. Microbiol., vol. 3. p. 344, 2012.

[14] A. Kumar, V. R. Falcao, and R. T. Sayre, "Evaluating nuclear transgene expression systems in Chlamydomonas reinhardtii," Algal Res., vol. 2, no. 4, pp. 321-332, 2013.

[15] B. Yang, J. Liu, Y. Jiang, and F. Chen, "Chlorella species as hosts for genetic engineering and expression of heterologous proteins: Progress, challenge and perspective," Biotechnol. J., vol. 11, no. 10. pp. 1244-1261, 2016.

[16] Y.-F. Niu, T. Huang, W.-D. Yang, J.-S. Liu, and H.-Y. Li, "Genetic engineering of microalgae," in Recent advances in microalgal biotechnology, H. Gerken, Z. Sun, and J. Liu, Eds. Heathrow, UK: OMICS International, p. 232., 2016.

[17] M. M. Allen and R. Y. Stanier, "Growth and division of some unicellular blue-green Algae," J. Gen. Microbiol., vol. 51, no. 2, pp. 199-202, 1968.

[18] S. F. Altschul, W. Gish, W. Miller, E. W. Myers, and D. J. Lipman, "Basic local alignment search tool," J. Mol. Biol, vol. 215, no. 3, pp. 403-410, 1990.

[19] T. Yamada, S. Maki, and T. Higashiyama, "Nucleotide sequence of a Chlorella vulgaris alpha-tubulin gene," Plant Physiol., vol. 11, no. 10, p. 1467, 1993.

[20] M. Lescot, "PlantCARE, a database of plant cis-acting regulatory elements and a portal to tools for in silico analysis of promoter sequences," Nucleic Acids Res., vol. 30, no. 1, pp. 325-327, 2002.

[21] Y. Nakamura, T. Gojobori, and T. Ikemura, "Codon usage tabulated from the international DNA sequence databases; its status 1999," Nucleic Acids Res., vol. 27, no. 1. p. 292, 1999. 
[22] P. Puigbò, E. Guzmán, A. Romeu, and S. Garcia-Vallvé, "OPTIMIZER: A web server for optimizing the codon usage of DNA sequences," Nucleic Acids Res., vol. 35, no. Suppl. 2, 2007.

[23] H. V. Perales-Vela, R. V. García, E. A. Gómez- Juárez, M. O. Salcedo-Álvarez, and R. O. Cañizares-Villanueva, "Streptomycin affects the growth and photochemical activity of the alga Chlorella vulgaris," Ecotoxicol. Environ. Saf., vol. 132, pp. 311-317, 2016.

[24] H. Qian et al., "Effects of streptomycin on growth of algae Chlorella vulgaris and Microcystis aeruginosa," Environ. Toxicol., vol. 27, no. 4, pp. 229-237, 2012.

[25] M. Sanitha, S. Radha, A. A. Fatima, S. G. Devi, and M. Ramya, "Agrobacterium-mediated transformation of three freshwater microalgal strains," Pol. J. Microbiol., vol. 63, no. 4, pp. 387-392, 2014.

[26] V. R. Yella and M. Bansal, "DNA structural features of eukaryotic TATA-containing and TATA-less promoters," FEBS Open Bio., vol. 7, no. 3, pp. 324-334, 2017.

[27] T. Meyer, J. Carlstedt-Duke, and D. B. Starr, "A weak TATA box is a prerequisite for glucocorticoid-dependent repression of the osteocalcin gene," J. Biol. Chem., vol. 272, no. 49, pp. 30709-30714, 1997.

[28] D. Choubey and R. Panchanathan, "Interferon-inducible Ifi200-family genes in systemic lupus erythematosus," Immunol. Let., vol. 119, no. 1-2, pp. 32-41, 2008.

[29] L. G. Zou et al., "High-efficiency promoter-driven coordinated regulation of multiple metabolic nodes elevates lipid accumulation in the model microalga Phaeodactylum tricornutum," Microb. Cell Fact., vol. 17, no. 1, 2018.

[30] J. P. Davies, D. P. Weeks, and A. R. Grossman, "Expression of the arylsulfatase gene from the $\beta 2$-tubulin promoter in Chlamydomonas reinhardtii," Nucleic Acids Res., vol. 20, no. 12, pp. 2959-2965, 1992.

[31] A. Hallmann and M. Sumper, "The chlorella hexose/H+ symporter is a useful selectable marker and biochemical reagent when expressed in volvox," Proc. Natl. Acad. Sci. U.S.A., vol. 93, no. 2, pp. 669-673, 1996.

[32] G. Blanc et al., "The Chlorella variabilis NC64A Genome Reveals Adaptation to Photosymbiosis, Coevolution with Viruses, and Cryptic Sex," Plant Cell, vol. 22, no. 9, pp. 2943-2955, 2010.

[33] C. Wang, Y. Wang, Q. Su, and X. Gao, "Transient expression of the GUS gene in a unicellular marine green alga,Chlorella sp.MACC/C95, via electroporation," Biotechnol. Bioprocess Eng, vol. 12, no. 2, pp. 180-183, 2007.

[34] L. L. Bai et al., "A new strategy to produce a defensin: stable production of mutated NP-1 in nitrate eeductase-deficient Chlorella ellipsoidea," PLoS One, vol. 8, no. 1, 2013. 